\title{
Prey Selectivity and Functional Response by Larval Red- Eyed Tetra Moenkhausia Sanctaefilomenae (Steindachner, 1907) (Characiformes: Characidae)
}

\author{
Jorge Gallardo Alanis, S.S.S. Sarma* and S. Nandini \\ Laboratory of Aquatic Zoology; Division of Research and Postgraduate Studies; National Autonomous University of \\ México; Campus Iztacala; AP 314; C.P.: 54090; Los Reyes; Tlalnepantla - State of Mexico - Mexico
}

\begin{abstract}
Studies were carried out to quantify the functional response and prey selectivity of larval (1-5 weeks old) of Moenkhausia sanctaefilomenae, a widely cultured ornamental fish, using four rotifers (Brachionus calyciflorus, B. havanaensis, B. patulus and B. rubens) as prey. Regardless of larval age, B. havanaensis was not selected, while B. rubens and B. calyciflorus were preferred. B. patulus was selected only after three weeks. When fed B. calyciflorus, the larvae showed increased prey consumption with increasing age, but remained as plateau around 80 prey individuals. M. sanctaefilomenae consumed much lower individuals of both B. havanaensis and B. patulus, while B. rubens was consumed in higher numbers starting from the first week (about 35 ind. larva-1 45 min.-1). Thus, the maximum number of individuals of each Brachionus species consumed by the larval M. sanctaefilomenae showed significant $(p<0.05)$ differences among the prey types.
\end{abstract}

Key words: Prey-predator interactions, zooplankton, fish-feeding, Brachionus

\section{INTRODUCTION}

Zooplankton is an important component of aquatic communities linking phytoplankton to icthyoplankton (Lampert and Sommer, 1997). Rotifers and cladocerans together with copepods constitute a major part of zooplankton composition in freshwaters (Hutchinson, 1967). Both rotifers and cladocerans are the ideal diet for great variety of both edible and ornamental fishes, due to their natural coexistence with fish, appropriate body size and nutritional quality (Hagiwara et al., 1997). In many aquacultural practices, heavy larval mortality of culturable fish species is considered as a major problem (Juanes, 1994). One of the means to reduce the larval mortality is to use zooplankton as the diet. During the initial larval stages (i.e., after the absorption of yolksac) live feed such as species of Brachionus or Moina are widely employed. However, the acceptability of a prey species by the larvae generally depends on its gape width (mouth size) (Rao, 2003).

Fish larvae are predominantly visual predators and therefore actively select prey items of larger size from a mixture of different zooplankton species. They also display a variety of behaviourial movements while attacking or capturing their prey (Sarma et al., 2003). During this process, some learning process takes place which eventually helps the fish larvae to capture the prey more

*Author for correspondence: sarma@ servidor.unam.mx 
efficiently and in higher numbers with increasing larval age. Therefore, quantity of prey consumed by a fish larva is dependent on its age (Gerking, 1994). Prey consumption rate is evaluated using functional response curves (Winkler and Orellana, 1990). For this, fish larvae of known age are offered a series of different densities of selected prey until a prey concentration beyond which the larvae will not be able to increase their consumption rate. Since the quantity of prey consumed increases with increasing age of fish larvae, the functional response curves are done periodically, i.e., weekly intervals (Peredo-Alvarez et al., 2004). Using prey selectivity studies, it is possible to offer the preferred prey in appropriate densities so as to obtain optimal larval growth. Prey selectivity by the fish larvae depends on, among other factors, the relative abundances of offered zooplankton species, their morphological characters including body size and behaviourial traits such as the swimming speed (Lazzaro, 1987).

The genus Moenkhausia is basically South American with about 60 known species (Lima and Toledo-Piza, 2001). One of widely cultured species of this genus is $M$. sanctaefilomenae. This is a tropical ornamental fish, first described from Santa Filomena on the Rio Parnahyba, Brazil. It is a small species (up to $7 \mathrm{~cm}$ length) and with high commercial value in many countries including Mexico. Like many other ornamental fishes of Characidae, $M$. sanctaefilomenae too experiences heavy larval mortalities, especially after the absorption of yolksac (which lasts about a week). Though adult food and feeding habits of this species are known (Esteves and Galetti, 1995), there is almost no information available on the prey selectivity or the quantity of zooplankton consumed during larval stages.

Since prey morphology, including the presence or the absence of defensive structures influences the capturability, it was hypothesized that rotifer prey with long spines were not actively selected by the fish larvae. The aim of the present work was, thus, to quantify the functional response and prey selectivity of larval Moenkhausia sanctaefilomenae using rotifer prey of different morphology.

\section{MATERIALS AND METHODS}

Reproductive Moenkhausia sanctaefilomenae were obtained from a commercial fish farm in Morelos (Mexico) and maintained in glass aquaria containing 40L of de-ionized water. Fertilized eggs were carefully separated from the adults and allowed to hatch. The hatchlings with small yolksac were not fed until one week and maintained on moderately hardwater (EPA medium), which was prepared by dissolving 96 $\mathrm{mg} \mathrm{NaHCO} 3,60 \mathrm{mg} \mathrm{CaSO}{ }_{4}, 60 \mathrm{mg} \mathrm{MgSO}_{4}$, and 4 $\mathrm{mg} \mathrm{KCl}$ in one litre of distilled water (Weber, 1993). The test conditions were similar for maintaining fish larvae and zooplankton species (temperature $23 \pm 0.5^{\circ} \mathrm{C}$, continuous but diffused fluorescent illumination and $\mathrm{pH}, 7.0-7.5$ ).

The fish larvae were offered ad libitum a mixture of four species of brachionid rotifers (Brachionus calyciflorus, B. havanaensis, B. patulus and $B$. rubens), all of which were cultured on the singlecelled green algae (Chlorella vulgaris) at a density of about $1 \times 10^{6}$ cells $/ \mathrm{ml}$. C. vulgaris was batchcultured using Bold's basal medium (Borowitzka and Borowitzka, 1988).

\section{Functional response}

Two different experiments were carried out: functional response and prey selectivity. Both these experiments were conducted during the early larval stages of $M$. sanctaefilomenae (for five weeks following the absorption of yolksac). The general experimental design was similar for both the experiments, i.e., use of pre-starved larvae (6 h) of known age, each treatment with five replicates of one larva each, $50 \mathrm{ml}$ capacity transparent test jars, each with $25 \mathrm{ml}$ EPA medium chosen prey type (and concentration or combination), continuous but diffused fluorescent illumination and $45 \mathrm{~min}$. feeding time.

For functional studies, carried out at weekly intervals, 20 larval M. sanctaefilomenae were used for each rotifer prey species and distributed into 20 test jars, each with $50,100,200$ or 400 individuals of B. calyciflorus, B. havanaensis, B. patulus or $B$. rubens. The prey population was introduced individually into each jar using finely drawn Pasteur pipette under stereomicroscope at a 
magnification of 20X. When the larvae were 4 week old, an additional prey density (i.e., 800 ind.) of one rotifer species (Brachionus rubens) was introduced for larvae of 4- and 5- week-old. The fish larvae were allowed to feed for $45 \mathrm{~min}$. after which they were removed and the uneaten rotifers were counted from each jar. The difference between the initial and final density of rotifers in each jar was considered as the prey number consumed by each larva. The data were transformed using Michaelis-Menten equation (Lampert and Sommer, 1997) for describing functional response curves: $y=a x /(b+x)$, where $x$ is the number of prey offered, $y$ is the number of prey consumed, $a$ is the $y$-intercept and $b$ is the slope. One-way analysis of variance (ANOVA) and Tukey's tests were used to quantify the differences in the maximal prey consumption of Brachionus species.

\section{Prey selectivity}

The prey selectivity experiment was conducted using mixed Brachionus species (in equal numbers). Into each of 5 test jars (combined prey, with 5 replicates), one pre-starved larva of $M$. sanctaefilomenae of the same age group was introduced and allowed to feed on the prey for 45 min. after which the fish larvae were separated and returned to stock. The rotifers in the test jars were fixed in $10 \%$ formalin for further analysis. Rotifers in the test jars were later quantified species-wise using a compound microscope at a magnification of $100 \mathrm{X}$. The difference between the initial and final density of each rotifer species in the test jars was considered as the prey number consumed by each larva.

Prey selectivity by larvae for each week was calculated using Manly's alpha: $\alpha_{i}=r_{i} / n_{i}\left(1 / \Sigma\left(r_{j} / n_{j}\right)\right)$ where, $\alpha_{i}=$ Manly's alpha for prey type $i ; r_{i}, r_{j}=$ proportion of prey type $i$ or $j$ in the diet ( $\mathrm{i}$ and $\mathrm{j}=$ $1,2,3$ and $4, \mathrm{~m}) ; n_{i}, n_{j}=$ proportion of prey type $\mathrm{i}$ or $\mathrm{j}$ in the environment; $m=$ number of prey species tested (4). When, $\alpha_{i}=1 / m(=0.25)$ feeding is not selective; $\alpha_{i}>1 / m(=>0.25$, then prey species $i$ is preferred in the diet and, $\alpha_{i}<1 / m$ (= $>0.25$ ), prey species $i$ is avoided in the diet (Krebs, 1993).

\section{RESULTS AND DISCUSSION}

Functional response curves of $M$. sanctaefilomenae fed $B$. calyciflorus showed increased prey consumption with increasing age of the larvae. Thus, when the larvae were one-week old, the quantity of prey consumed was stabilized about 20 ind./larva. On the other, when the larvae were 5-week old, the prey consumption was plateaued around 80 ind. larva ${ }^{-1}$ (Fig. 1a). Functional response curves of larval $M$. sanctaefilomenae in general slowed much lower prey (B. havanaensis) consumption with increasing rotifer density. Thus, when the larvae were as old as five weeks, the prey consumption reached an asymptote of about 50 ind./larva (Fig. $1 b)$. When $B$. patulus was used as the prey, the functional response curves were similar to those obtained for $B$. havanaensis, although when the larvae were one-week old, they were able to consume less than 5 prey per larva, even when the offered prey density was 400 individuals per jar (Fig. 2a). B. rubens was, in general, consumed in higher numbers starting from the first week (about 35 ind. $\left.\operatorname{larva}^{-1}\right)$. The prey consumption was nearly plateaued when the offered prey density was 800 individuals per jar (Fig. 2b).

One-way analysis of variance conducted on the maximum number of individuals of each Brachionus species consumed by the larvae of 5week old showed significant $(\mathrm{p}<0.05$, F-test, Table $1)$ differences among the prey types. When these data were subjected to further analysis, there was no significant difference $(\mathrm{p}>0.05)$ between the prey species $B$. havanaensis and $B$. patulus but for the rest it was significant ( $\mathrm{p}<0.05$, Tukey's test).

Table 1 - Results of one-way analysis of variance (ANOVA) performed on the maximum prey consumption by the larval Moenkhausia sanctaefilomenae ( $5^{\text {th }}$ week old) fed B. calyciflorus, B. havanaensis, B. patulus and B. rubens.

\begin{tabular}{lcccc}
\hline Source of variation & DF & SS & MS & F-ratio \\
\hline Among prey types & 3 & 52784 & 17594 & $837 * * *$ \\
Error & 16 & 336 & 21 & \\
\hline
\end{tabular}

$\mathrm{DF}=$ degrees of freedom, $\mathrm{SS}=$ sum of squares, $\mathrm{MS}=$ mean square, F-relation (Fischer), $* * *=\mathrm{p}<0.001$. 

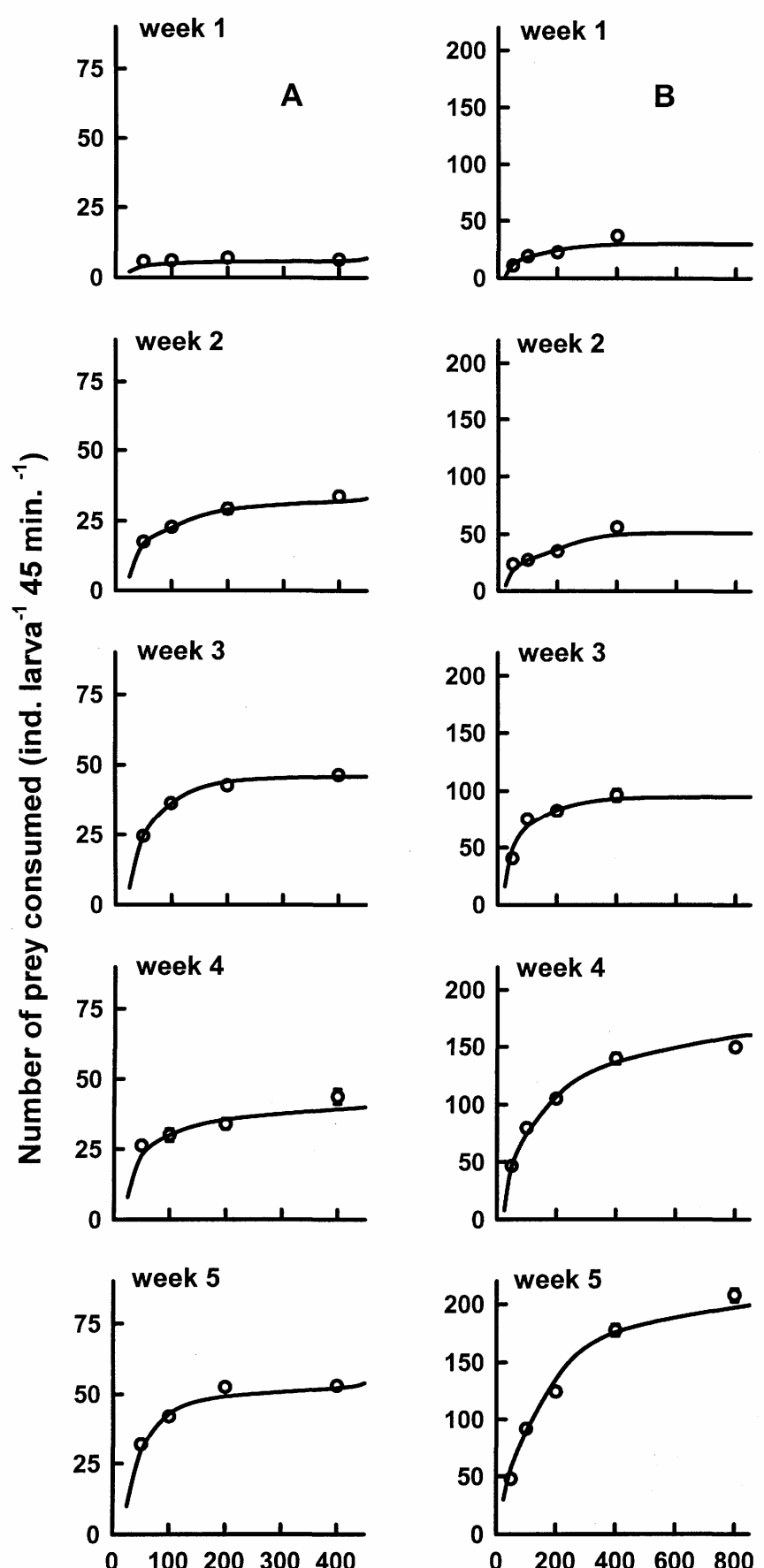

Prey density (ind.)

Figure 1 - Relationship between the rate of prey (A: Brachionus calyciflorus and B: Brachionus havanaensis) ingestion (mean \pm standard error, based on 5 replicates) by larval Moenkhausia sanctaefilomenae and the rotifer density. 


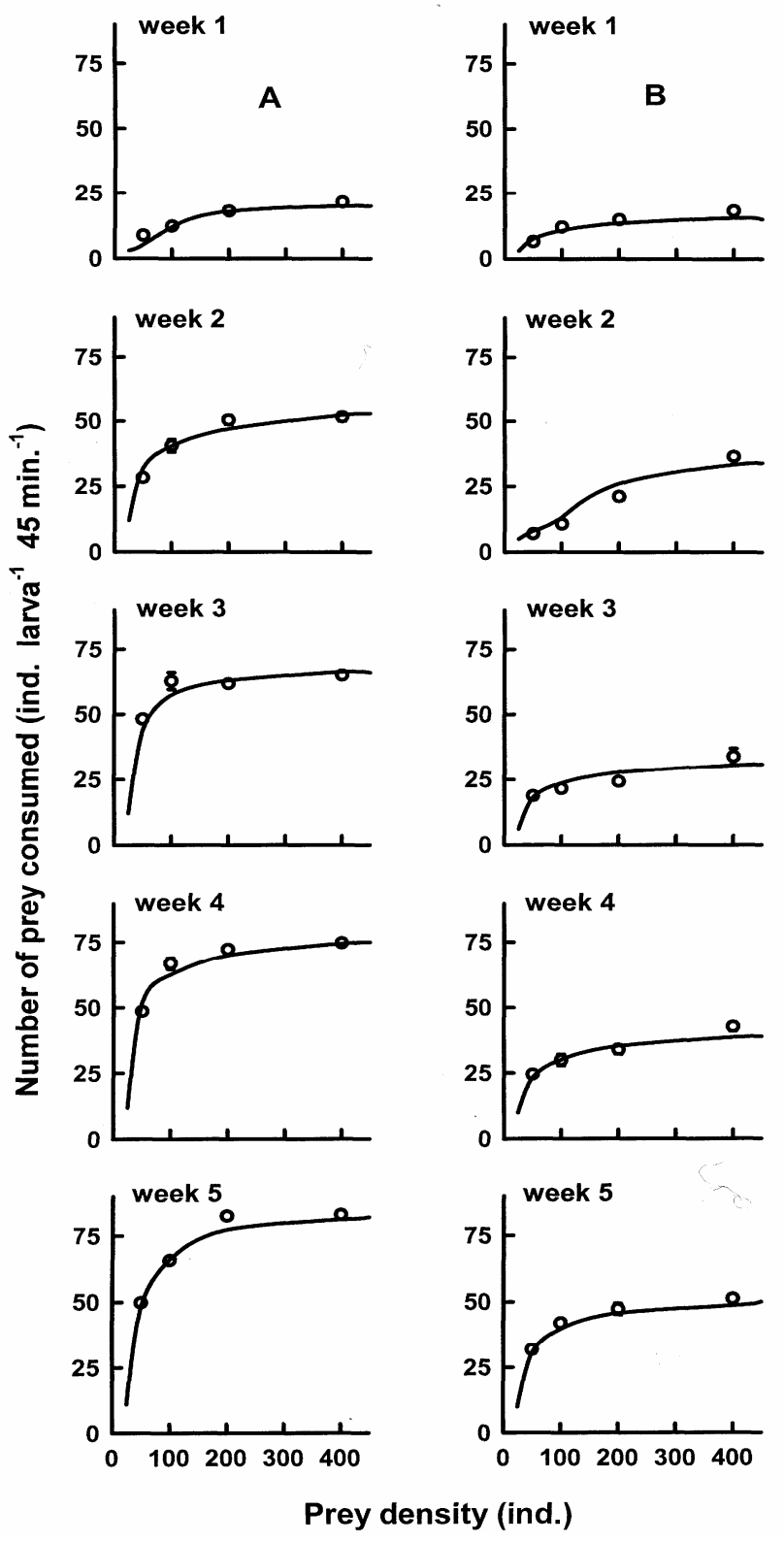

Figure 2 - Relationship between the rate of prey (A: Brachionus patulus and B: Brachionus rubens) ingestion (mean \pm standard error, based on 5 replicates) by larval Moenkhausia sanctaefilomenae and the rotifer density.

The trends in functional response were largely reflected in the data of prey selectivity experiments. Regardless of larval age, $B$. havanaensis was not selected, while both $B$. rubens and B. calyciflorus were positively selected regardless of the larval age of $M$. sanctaefilomenae. B. patulus was not selected for the three weeks but thereafter, it was positively selected (Fig. 3).
Food and feeding habits of ornamental fishes of Characidae are known mostly from the gut content studies on adults collected through seasons from natural waterbodies (Peretti and Fatima-Andrian, 2004). Though the variety of prey available for a given fish larva in natural waterbodies is much higher than those provided by the laboratory studies, based on gut content studies, it is often difficult to identify the prey up to species level, 
especially when the prey is soft-bodied, which is the case of all rotifer species and a few cladocerans (e.g., Moina) (Gerking, 1994).

Depending on the fish species, either rotifers or cladocerans or in some cases both, are used for feeding fish larvae (Domínguez-Domínguez et al., 2002). For example, in a study on the zooplankton preference by larval mollies and angel fish, Nandini and Sarma (2000) have observed that the former preferred rotifers, while the latter the cladocerans. In this study too, cladocerans (Moina macrocopa and Ceriodaphnia dubia) were given as prey for larval $M$. sanctaefilomenae but hardly any prey item was consumed by larvae of 5 weekold. Therefore, this study was restricted to rotifer prey only. Brachionus is a pantropical genus and coexists with Moenkhausia (Arcifa et al., 1996; Lima and Toledo-Piza, 2001). Therefore, the use of brachionid prey in this study could reflect natural prey-predator interactions, though they were not sampled for the rotifer species from the type locality of $M$. sanctaefilomena.

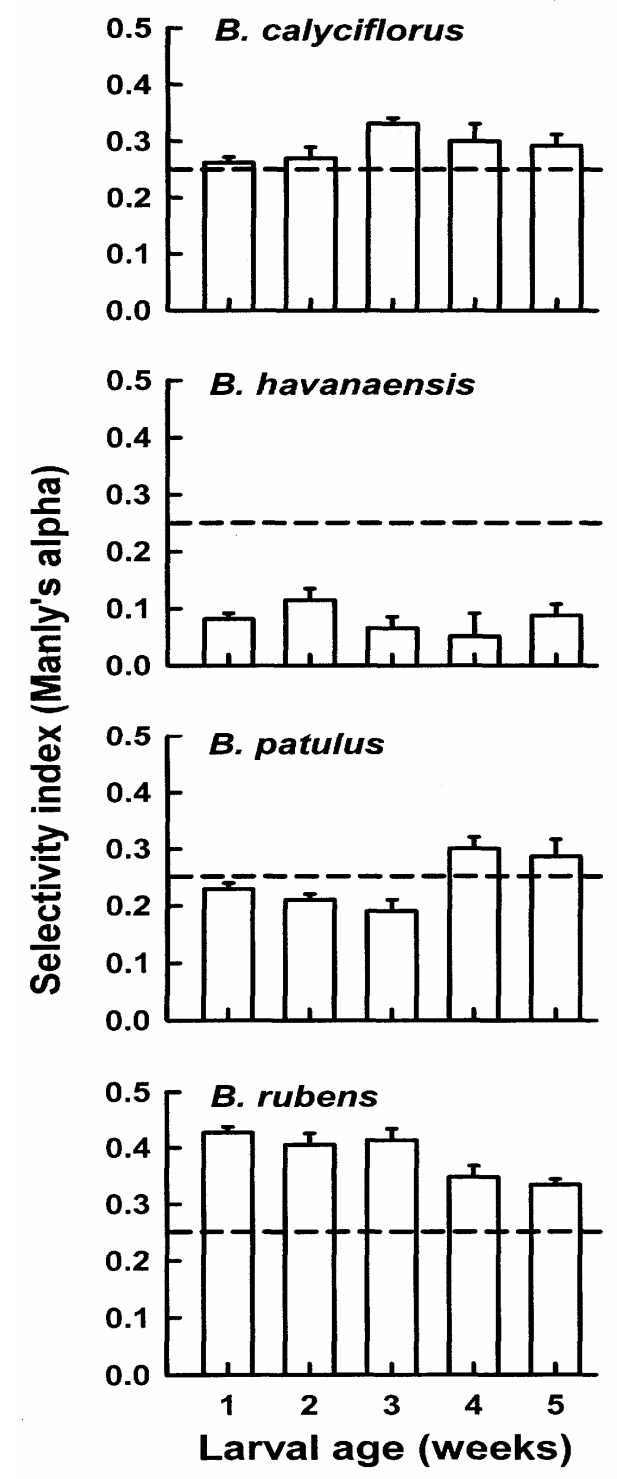

Figure 3 - Prey (Brachionus) selectivity (Manly's $\alpha$ ) by Moenkhausia sanctaefilomenae in relation to larval age (weeks). Data bars lying below the horizontal line indicate absence of selectivity. Values represent mean \pm standard error, based on 5 replicates. 
The rotifer prey densities offered for the functional response or the prey selectivity study were based on information available in literature. For example, Morales-Ventura et al. (2004) have used different densities (25 to 800 individuals) of $B$. rotundiformis and $B$. rubens for deriving the functional response curves of the charal fish Chirostoma riojai. They obtained peak consumption of about 300 to 450 rotifers per larva six week old. In addition, compared to $B$. rotundiformis, larval charal consumed much higher number of $B$. rubens. In the present study too, $B$. rubens was consumed in greater numbers than other prey species. Of the four prey species used here, $B$. havanaensis and $B$. patulus have spines, while $B$. rubens and $B$. calyciflorus have very small (about $10 \mu \mathrm{m}$ ) anterior spines. There is overwhelming data which show that fish larvae feed more efficiently on prey without (or with very small) spines such as $B$. plicatilis, $B$. rubens and $B$. calyciflorus (Zaret, 1980). B. calyciflorus may develop long posterior and postero-lateral spines in the presence of invertebrate predators such as Asplanchna and cyclopoid copepods. However, when cultured under laboratory conditions, $B$. calyciflorus remained predominantly spineless (Gilbert, 1998) and this was the condition in the present rotifer cultures.

In general, many species of fish show type 2 functional response, i.e., the rate of consumption increases with increasing prey density but gradually decelerates until a plateau is reached at which the rate of consumption remains the same regardless of the prey density (Morales-Ventura et al., 2004). Most larval fish experience prey handling problems when the prey items are available in large quantities, especially when the larvae are 1 or 2 two-week old. With increase in larval age, prey capture and handling skills improve, therefore fish larvae may continue to consume higher numbers with increasing prey densities and thus the rate of consumption reaches a plateau at a level higher than that from younger larvae (Rao, 2003). This also was evident in the present study for all the prey species.

Prey preference is a measure of prey selectivity when all food types are equally available for a predator in the medium (Greene, 1983). In this study, all the prey species were offered in equal numbers and, therefore, were considered equally available for the larval M. sanctaefilomenae. Since this was continued for five weeks, it was possible to derive data on prey preferences by larvae of different ages. All the four species of Brachionus used here had the adult body size (spines excluded) in the range of $120-160 \mu \mathrm{m}$ and had nearly similar swimming speeds (about $1 \mathrm{~mm} / \mathrm{sec}$.) (Sarma, 1991). Therefore, active selection by the larvae depended on the prey morphology (i.e., presence or absence of defense structures). As observed in functional response experiment, larval $M$. sanctaefilomenae preferred $B$. rubens and $B$. calyciflorus, both of which had no large spines. $B$. havanaensis was avoided while $B$. patulus was preferred by older age-group larvae. These two species had long anterior or posterior spines. Prey defenses may also interfere with both the selectivity and the rate of prey items consumed. Since $B$. havanaensis had long posterior spines, this species was not positively selected by the larval $M$. sanctaefilomenae (and $B$. patulus by older age group larvae). Thus, this observation was consistent with other prey selection studies which showed the lack of preference for prey items with strongly developed morphological defenses (Zaret, 1980). The body size differences (excluding spines) in the prey species tested in this study was about $40 \mu \mathrm{m}$, which did not appear to be wide enough to influence the outcome of selectivity, considering that fish larvae showed some degree of flexibility in the gape diameter while capturing prey items (Rao, 2003).

While comparing the patterns of prey selectivity, Nandini and Sarma (2000) observed that larval mollies preferred B. calyciflorus. In a preliminary study, it was observed that $M$. sanctaefilomenae did not consume cladocerans possibly due to gape limitation. In this study mouth size was not measure at regular intervals. However, gape measurements of a few larvae of different ages (up to 5 week old) was done, which varied from 200 to $350 \mu \mathrm{m}$. This confirmed our preliminary observation that cladocerans were not eaten by larval $M$. sanctaefilomenae. However, gut content analysis of field-collected individuals would be still needed to understand the diet breadth of $M$. sanctaefilomenae during larval stages. The assimilation strategies of consumed prey by larval $M$. sanctaefilomenae were not known and the assimilation efficiency was also not studied. It is known that it depends on the nutritional quality of prey, among other factors (Gerking, 1994). Since the prey species used here belonged to the same genus and that these were all cultured under similar conditions, it could be assumed that nutritional quality of Brachionus species remained 
nearly the same. However, the evaluation of the nutritional quality of the prey is still needed to understand the assimilation strategies of larval $M$. sanctaefilomenae.

\section{ACKNOWLEDGEMENTS}

One of authors (JGA) is grateful to Luis Zambrano González, Javier Alcocer Durand and Felipe Amezcua Linares for useful discussion.

\section{REFERENCES}

Arcifa, M. S., Castilho, M. S. M., Carmouze, J. P. (1996), Composition and evolution of zooplankton in a Brazilian coastal lagoon during a period characterised by a fish kill. Revue D'Hydrobiologie Tropicale, 27, 251-263.

Borowitzka, M. A., Borowitzka, L. J. (1988), Microalgal biotechnology. Cambridge University Press, United Kingdom.

Domínguez-Domínguez, O., Nandini, S., Sarma, S. S. S. (2002), Larval feeding behaviour of the endangered fish golden bubblebee goodeid, Allotoca dugesi (Bean) (Goodeidae) offered zooplankton: implications for conservation. Fisheries Management and Ecology, 9, 285-291.

Esteves, K. E., Galetti, P. M. Jr. (1995), Food partitioning among some characids of a small Brazilian floodplain lake from the Parana River basin. Environmental Biology of Fishes, 42, 375-389.

Gerking, S. D. (1994), Feeding ecology of fish. Academic Press, London.

Gilbert, J. J., (1998), Kairomone-induced morphological defenses in rotifers. In-The ecology and evolution of inducible defenses, ed. R. Tollrian and C.D. Harvell. Princeton University Press, Princeton, pp. 127-141.

Greene C. H. (1983), Selective predation in freshwater zooplankton communities. International Revue der gesamten Hydrobiologie, 68, 297-315.

Hagiwara, A., Snell T.W., Lubzens, E., Tamaru, C.S. (eds). (1997). Live food in marine larviculture. Hydrobiologia vol. 358.

Hutchinson, G.E. (1967), A treatise on limnology. 2. Introduction to lake biology and limnoplankton. John Wiley, New York.

Juanes, F., 1994. What determines prey size selectivity in piscivorous fishes? In- Theory and application in fish feeding ecology, ed. D.J. Stouder, K. L. Fresh, R. J. Feller. The Belle W. Baruch Library in Marine Science No. 18 University of South Carolina Press. USA, pp. 79-100.
Krebs J. R. (1993), Ecological Methodology. Harper Collins Publ., New York.

Lampert, W., Sommer, U. (1997), Limnoecology. The ecology of lakes and streams. Oxford University Press, New York.

Lazzaro, X. (1987), A review of planktivorus fishes: Their evolution, feeding behavior, selectivities and impacts. Hydrobiologia, 146, 97-167.

Lima, F.C.T., Toledo-Piza, M. (2001), New species of Moenkhausia (Characiformes: Characidae) from the Rio Negro of Brazil. Copeia, 2001 (4), 1058-1063.

Morales-Ventura, J., Nandini, S., Sarma, S.S.S. (2004), Functional responses during the early larval stages of the charal fish Chirostoma riojai (Pisces: Atherinidae) fed zooplankton (rotifers and cladocerans). Journal of Applied Ichthyology, 20, 417-421.

Nandini, S., Sarma, S.S.S. (2000), Zooplankton preference by two species of freshwater ornamental fish larvae. Journal of Applied Ichthyology, 16, 273275.

Peredo-Alvarez, V.M., Sarma, S.S.S., Nandini, S. (2004), Studies on the functional responses of the Mexican live bearer fish Allotoca meeki (Goodeidae: Cyprinodontiformes). In-Advances in fish and wildlife ecology and biology, ed. B. L. Kaul. Vol. 3, Daya Publishing House, Delhi, India, pp. 27-40.

Peretti, D., Fatima-Andrian, I. (2004). Trophic structure of fish assemblages in five permanent lagoons of the High Parana River floodplain, Brazil. Environmental Biology of Fishes, 71, 95-103.

Rao, T. R. (2003), Ecological and ethological perspectives in larval fish feeding. Journal of Applied Aquaculture, 13, 145-178.

Sarma, S.S.S. (1991), Rotifers and aquaculture (Review). Environment and Ecology, 9, 414-428.

Sarma, S.S.S., López-Rómulo, J.A., Nandini, S. (2003), Larval feeding behaviour of blind fish Astyanax fasciatus (Characidae), black tetra Gymnocorymbus ternetzi (Characidae) and angel fish Pterophyllum scalare (Cichlidae) fed zooplankton. Hydrobiologia, 510, 207-216.

Weber, C. I. (1993), Methods for measuring the acute toxicity of effluents and receiving waters to freshwater and marine organisms. 4th ed. United States Environmental Protection Agency, Cincinnati, Ohio.

Winkler, H., Orellana, C. (1990), Functional responses of five cyprinid species to planktonic prey. Environmental Biology of Fishes, 33, 53-62.

Zaret, T.M. (1980), Predation and freshwater communities. Yale University Press, New Haven, USA. 